\title{
Effects of L-glutamine supplementation on degradation rate and rumen fermentation characteristics in vitro
}

\author{
Jung-Keun Suh ${ }^{1}$, Jalil Ghassemi Nejad ${ }^{1}$, Yoon-Seok Lee ${ }^{2}$, Hong-Sik Kong ${ }^{3}$, \\ Jae-Sung Lee ${ }^{1}$, and Hong-Gu Lee ${ }^{1 \text {,* }}$
}

\author{
* Corresponding Author: Hong-Gu Lee \\ Tel: +82-2-4500410, Fax: +82-2-4533669, \\ E-mail: hglee66@konkuk.ac.kr \\ 1 Department of Animal Science and \\ Technology, Sanghuh College of Life \\ Sciences, Konkuk University, Seoul 05029 \\ Korea \\ 2 Department of Biotechnology, College of \\ Agriculture and Life Science, Hankyong \\ National University, Anseong 17579, Korea \\ ${ }^{3}$ Gyeonggi Regional Research Center, \\ Hankyong National University, Anseong \\ 17579, Korea \\ ORCID \\ Jung-Keun Suh \\ https://orcid.org/0000-0002-6919-1867 \\ Jalil Ghassemi Nejad \\ https://orcid.org/0000-0001-6578-8829 \\ Yoon-Seok Lee \\ https://orcid.org/0000-0003-4803-5192 \\ Hong-Sik Kong \\ https://orcid.org/0000-0003-1144-016X \\ Jae-Sung Lee \\ https://orcid.org/0000-0001-8940-9862 \\ Hong-Gu Lee \\ https://orcid.org/0000-0002-0679-5663
}

Submitted Jun 15, 2021; Revised Jul 23, 2021; Accepted Sept 7, 2021
Objective: Two follow-up studies (exp. 1 and 2) were conducted to determine the effects of L-glutamine (L-Gln) supplementation on degradation and rumen fermentation characteristics in vitro.

Methods: First, rumen liquor from three cannulated cows was used to test L-Gln (50 mM) degradation rate and ammonia-N production at $6,12,24,36$, and $48 \mathrm{~h}$ after incubation (exp. 1). Second, rumen liquor from two cannulated steers was used to assess the effects of five levels of L-Gln including $0 \%$ (control), $0.5 \%, 1 \%, 2 \%$, and $3 \%$ at $0,3,6,12,24,36$, and $48 \mathrm{~h}$ after incubation on fermentation characteristics, gas production, and degradability of nutrients (exp. 2).

Results: In exp. 1, L-Gln degradation rate and ammonia-N concentrations increased over time $(\mathrm{p}<0.001)$. In exp. $2, \mathrm{pH}$ was reduced significantly as incubation time elapsed $(\mathrm{p}<0.001)$. Total gas production tended to increase in all groups as incubation time increased. Acetate and propionate tended to increase by increasing glutamine (Gln) levels, whereas levels of total volatile fatty acids (VFAs) were the highest in $0.5 \%$ and $3 \%$ Gln groups $(\mathrm{p}<0.001)$. The branched-chain VFA showed both linear and quadratic effects showing the lowest values in the $1 \%$ Gln group particularly after $6 \mathrm{~h}$ incubation $(\mathrm{p}<0.001)$. L-Gln increased crude protein degradability $(\mathrm{p}<0.001)$, showing the highest degradability in the $0.5 \% \mathrm{Gln}$ group regardless of incubation time $(\mathrm{p}<0.05)$. Degradability of acid detergent fiber and neutral detergent fiber showed a similar pattern showing the highest values in $0.5 \% \mathrm{Gln}$ group $(\mathrm{p}<0.10)$.

Conclusion: Although L-Gln showed no toxicity when it was supplemented at high dosages ( $2 \%$ to $3 \%$ of DM), $0.5 \% \mathrm{~L}-\mathrm{Gln}$ demonstrated the positive effects on main factors including VFAs production in-vitro. The results of this study need to be verified in further in-vivo study.

Keywords: L-glutamine; Degradability of Nutrients; Degradation Rate; Gas Production; In-vitro Fermentation

\section{INTRODUCTION}

Glutamine (Gln), a conditionally essential amino acid (AA) in animals [1,2], is the most abundant free AA in the body [2]. It encompasses about $60 \%$ of free AA in skeletal cells $[3,4]$ and $20 \%$ in plasma [5]. Furthermore, L-Gln has a wide range of cellular and physiological functions including protein synthesis [6], lipid metabolism, and cell growth [7,8], all of which are associated with muscle growth and proliferation [9]. By inducing lymphocyte proliferation, Gln is considered as booster of immune system. Gln also is important in control of metabolic acidosis. Gln involves in the nucleic acid biosynthesis that is necessary to support cell proliferation [10]. Gln may provide a protective effect against hepatic AA oxidation, particularly for methionine (Met) that showed the anabolic potential of 
Gln since the Met is considered as the first limiting AA in many of ruminant's feeds [10]. Besides having many proposed metabolic roles, responses to Gln supplementation have been reportedly inconsistent whereas both positive and null effects on production responses have been reported [10]. Understanding the optimum level of Gln supplementation by performing in-vitro study will assist to make a better decision to maximizing the muscle growth in empirical in-vivo studies in beef cattle while help avoiding possible toxic level(s). The effects of AA supplementation on the production of volatile fatty acids (VFAs) triggered by ruminal microorganisms that ultimately can affect cell growth and production performance is of importance [11,12]. Warner [13] stated that microorganisms from the rumen of sheep rapidly break down Gln to other components such as asparagine and nicotinamide resulting in exceeding ammonia production which in turn can lead to Gln synthesis. This phenomenon implies that although some AAs such as Gln (and asparagine) are more likely to rapidly break down by rumen microorganism to ammonia and microbial protein [13], they are the first to be anabolized or derived from the microbial protein in forestomach by utilizing ammonia $[14,15]$ or in latter gastrointestinal tract (i.e. duodenum) and later responsible for over $50 \%$ of AAs entering to the blood stream [16]. Lately, Apajalahti et al [17] have reported positive effects of branched chained AAs, which have different metabolism pathways than Gln, on the yield of branched chained VFA that can be used to estimate the degree of protein degradation. Ruminants have capacity of the forestomach mucosa to utilize ammonia to synthesize Gln and glutamate (Glu) [14,15]. Given this and due to the enormous role of Gln on protein synthesis, cellular and microorganism growth and development, we hypothesized that L-Gln supplementation has potential to positively effect rumen fermentation characteristics in ruminants that need to be first tested in vitro. Although recent studies have determined effects of supplementation of valine, leucine, and isoleucine on $\mathrm{pH}$, ammonia- $\mathrm{N}$, branchedchained VFA [11,17], and nutrient digestibility in-vitro [18], in-vitro effects of L-Gln supplementation at various levels with different incubation time on substrate degradation and fermentation characteristics have not been examined. Thus, the objectives of this study were: i) to determine effects of LGln supplementation on its in-vitro degradation rate and ammonia-N production; ii) to determine the optimum level(s) of L-Gln supplementation without toxic effects; and iii) to investigate the effects of L-Gln supplementation on fermentation characteristics including VFA, gas production, and degradability of nutrients. Results of this study can be used to acquire the optimum level of L-Gln for future in-vivo studies when maximum cell growth is targeted and to avoid possible toxic level(s).

\section{MATERIALS AND METHODS}

\section{Experiment 1}

Animals, diets, and ruminal liquor substrate: All animal procedures were approved by the Institution of Animal Care and Use Committee at Konkuk University (approval no. KU19075). Rumen liquor was obtained from three non-lactating Holstein cows at 30-month old (body weight [BW] = $735 \pm 25 \mathrm{~kg}$ ) fed diets (Table 1) made of forage (F) and concentrate (C) on the basis of total mixed ration (TMR) at a $\mathrm{F}: \mathrm{C}=6: 4$ ratio ad libitum (exp. 1). These cows had free access to clean drinking water. Feed was provided daily at 09:00. The animals were surgically cannulated. Thus, rumen liquor could be obtained directly from the rumen. Two hours before feeding, ruminal contents from different cattle were combined and squeezed through two-layers of cheesecloth to remove feed particles. After filteration, the rumen liquor was transported to the laboratory using the pre-warmed $\left(39^{\circ} \mathrm{C}\right)$ bottles that were vacuumed for making oxygen-free environment by inclusion of free carbon dioxide $\left(\mathrm{CO}_{2}\right)$ into the headspace prior to the handling. McDougall's [19] buffer solution (Table 2) was prepared. The $\mathrm{pH}$ of the buffer was adjusted to 6.8 under continuous flushing of $\mathrm{CO}_{2}$ for making anaerobic condition with constant magnetic stirring at $39^{\circ} \mathrm{C}$. The buffer solution and rumen liquor were mixed at a ratio of 4:1 and $50 \mathrm{~mL}$ of the rumen inoculum was filled into prewarmed $\left(39^{\circ} \mathrm{C}\right)$ serum bottles. The headspace of the bottle was saturated with $\mathrm{CO}_{2}$. Bottles were capped with butyl rubber stoppers, sealed with center tear seals, and vortexed. Thereafter, samples were incubated in a thermostatically controlled incubator $\left(39^{\circ} \mathrm{C}, 100 \mathrm{rpm}\right)$ for $48 \mathrm{~h}$. There was no feed contained. Only L-Gln (Daesang Co., Seoul, Korea) was incubated at two levels of 0 and $50 \mathrm{mM}$ in three independent runs. Each level of 0 and $50 \mathrm{mM} \mathrm{L-Gln}$ was incubated in triplicate

Table 1. Chemical compositions of the experimental diet (exp. 1)

\begin{tabular}{lccc}
\hline Chemical composition & $\begin{array}{c}\text { Forage } \\
\text { (F) }\end{array}$ & $\begin{array}{c}\text { Concentrate } \\
\text { (C) }\end{array}$ & $\begin{array}{c}\text { Total mixed ration } \\
\text { (F:C = 6:4) }\end{array}$ \\
\hline Dry matter & 88.1 & 86.6 & 62.4 \\
Crude protein & 4.1 & 13.5 & 10.0 \\
Crude fat & 0.7 & 3.7 & 2.6 \\
Neutral detergent fiber & 31.2 & 8.8 & 16.9 \\
Acid detergent fiber & 4.4 & 6.0 & 5.0 \\
\hline
\end{tabular}

The values are in \%.

Table 2. Chemical compositions of McDougall's buffer (exp. 1)

\begin{tabular}{lc}
\hline Ingredient composition & Amount $\left(\mathbf{g} / \mathbf{L} \mathbf{~} \mathbf{H}_{\mathbf{2}} \mathbf{0}\right)$ \\
\hline $\mathrm{NaHCO}_{3}$ (Sodium carbonate) & 9.80 \\
$\mathrm{Na}_{2} \mathrm{HPO}_{4}$ (Sodium phosphate) & 3.69 \\
$\mathrm{KCl}$ (Potassium chloride) & 0.57 \\
$\mathrm{NaCl}$ (Sodium chloride) & 0.47 \\
$\mathrm{MgSO}_{4}$ (Magnesium sulfate) & 0.12 \\
\hline
\end{tabular}


to improve the reliability of the assessment. The sampling time was $0,6,12,24,36$, and $48 \mathrm{~h}$, resulting in a total of 30 bottles per incubation ( 2 level $\times 5$ sampling time $\times 3$ replicates).

Ammonia-nitrogen analysis: Concentrations of ammonia-nitrogen (ammonia- $\mathrm{N})(\mathrm{mg} / 100 \mathrm{~mL})$ were determined according to protocol of Chaney and Marbach [20] in triplicates. For this, $0.01 \mathrm{~mL}$ of $\mathrm{HgCl}_{2}$ was added into $1 \mathrm{~mL}$ of rumen liquor sample. The mixture was then centrifuged at $3,000 \mathrm{rpm}$ for $20 \mathrm{~min}$ at $4^{\circ} \mathrm{C}$ to collect the supernatant. After collection, $0.02 \mathrm{~mL}$ of the supernatant and ammonia $\mathrm{N}$ Standard solution $(25,50,100,200$, and $400 \mathrm{ppm}), 0.01 \mathrm{~mL}$ of alkali-hypochlorite, and phenol color reagent were added to a well of a plate and incubated at $50^{\circ} \mathrm{C}$ for $7 \mathrm{~min}$. Thereafter, plates were read at $630 \mathrm{~nm}$ using a spectrophotometer (680, BIO-RAD, Hercules, CA, USA) to determine ammonia-N concentration. The degradation rate was calculated with the following formula: degradation rate $=(36 \mathrm{~h}$ ammonia$\mathrm{N}-0 \mathrm{~h}$ ammonia- $\mathrm{N}) /(\chi \mathrm{h}$ ammonia- $\mathrm{N}-0 \mathrm{~h}$ ammoniaN) $\times 100$.

\section{Experiment 2}

Animals, diets, and ruminal liquor substrate: Rumen liquor from two non-lactating Korean native cows at 24-month old $(\mathrm{BW}=475 \pm 25 \mathrm{~kg})$ were exploited in exp. 2. Animals were fed diet (Table 3) of TMR ad libitum. Feed was provided daily at 09:00. All other conditions were the same as in exp. 1.

Two experiments were proceeded for determining the effects of L-Gln supplementation at levels of $0 \%, 0.5 \%, 1 \%$, $2 \%$, and $3 \%$ on fermentation characteristics, gas production, and rumen nutrient degradability. First, TMR was ground

Table 3. Ingredients and chemical compositions of the diet (exp. 2)

\begin{tabular}{lc}
\hline Item & Amount \\
\hline Ingredients (\% dry matter) & 20.6 \\
Corn flake & 18.3 \\
Soybean curd residue & 18.3 \\
Yeast & 11.4 \\
Rice straw & 6.9 \\
Soybean pellet & 6.9 \\
Soybean hulls & 6.9 \\
Corn gluten meal & 4.5 \\
Rice flour & 2.3 \\
Bakery by-product & 2.3 \\
Sesame oil meal & 1.0 \\
Limestone & 0.6 \\
NaCl & \\
Chemical composition (\%) & 38.1 \\
Moisture & 14.2 \\
Crude protein & 41.7 \\
Neutral detergent fiber & 23.3 \\
Acid detergent fiber & 2.7 \\
Crude fat & 5.8 \\
Crude ash & 1.3 \\
Glutamic acid &
\end{tabular}

and $0.5 \mathrm{~g}$ was added to a bottle and incubated with L-Gln (Daesang Co., Korea) at 5 levels $(0 \%, 0.5 \%, 1 \%, 2 \%$, and $3 \%)$ in three independent runs. Each level was incubated in triplicate, whereas sampling time was $0,6,12,24,36$, and $48 \mathrm{~h}$, resulting in a total of 75 bottles per incubation ( 5 levels $\times 5$ sampling times $\times 3$ replicates). Second, TMR was ground, and $1.5 \mathrm{~g}$ was added to an ANKOM filter bag (filter bag 57, ANKOM, Macedon, NY, USA). Three independent bags were put in one bottle and incubated with L-Gln at five levels $(0 \%, 0.5 \%, 1 \%, 2 \%$, and $3 \%)$. Sampling time was $0,12,24$, and $48 \mathrm{~h}$, resulting in a total of 20 bottles per incubation (5 levels $\times 4$ sampling times). The method was modified with DAISY incubator (ANKOM, 2017).

Ammonia- $\mathrm{N}, \mathrm{pH}$, and volatile fatty acids analyses: Ammonia- $\mathrm{N}$ was measured according to the same procedure as explained in exp. 1. The $\mathrm{pH}$ was measured with a $\mathrm{pH}$ meter (MP230, Mettler Toledo, Columbus, OH, USA) for each sampling time $(0,6,12,24,36$, and $48 \mathrm{~h})$. Volatile fatty acid concentration was determined according to method of Erwin et al [21] in triplicates. For this, $0.1 \mathrm{~mL}$ of phosphoric acid $(25 \%, \mathrm{w} / \mathrm{v})$ and $0.2 \mathrm{~mL}$ pivalic acid solution $(2 \%, \mathrm{w} / \mathrm{v})$ were added into $1 \mathrm{~mL}$ of rumen liquor sample. The mixture was then centrifuged at $12,000 \mathrm{rpm}$ for $30 \mathrm{~min}$ at $4^{\circ} \mathrm{C}$. The supernatant was collected and stored at $-80^{\circ} \mathrm{C}$ before analysis. The VFA standard was prepared by adding each reagent (Supplementary Table 2-1). Thereafter, samples were analyzed to measure VFAs using a gas chromatograph (HP6890, Agilent, Mundelein, IL, USA).

Degradability of dry matter, crude protein, neutral detergent fiber, and acid detergent fiber analyses: Dry matter (DM) was determined followed by weighing a sample after drying at $60^{\circ} \mathrm{C}$ for $48 \mathrm{~h}$ in a dry oven. The in-vitro DM degradation calculation model was as follows: DM (\%) = dried residue / sample weight $\times 100$. Crude protein $(\mathrm{CP})$ was determined using an elemental analyzer (EA 1110, CE instruments, USA). The in-vitro $\mathrm{CP}$ degradation was calculated with the following formula: $\mathrm{CP}(\%)=\mathrm{N}(\%) \times 6.25$. In detail, $3 \mathrm{mg}$ of feed was weight with an ultrafine scale and added into a tin solid capsule (PN 240 06400, Thermo Scientific, Coatesville, PA, USA). Sulfanilammide standard (Supplementary Tables 2-4) was prepared the same as a sample for analysis. Neutral detergent fiber (NDF) and acid detergent fiber (ADF) were measured according to the procedure provided by ANKOM Technology. Doing these fiber analyses, $0.45 \mathrm{~g}$ of feed was added to ANKOM filter bag (filter bag 58, ANKOM, USA) followed by sealing the bags. Afterwards, the sealed bags were drowned in acetone for $10 \mathrm{~min}$ and then dried for another $10 \mathrm{~min}$. After drying, samples were placed into the ANKOM fiber analyzer machine (ANKOM 200, ANKOM, USA). The NDF solution (Supplementary Table 2-2), $4 \mathrm{~mL}$ a-amylase, and $20 \mathrm{~g}$ sodium sulfate anhydrous were then added to the solution. The mixture was then heat activated 
at $100^{\circ} \mathrm{C}$ for $75 \mathrm{~min}$. After heating, samples were washed in the machine for $12 \mathrm{~min}$ with $2 \mathrm{~L}$ of distilled water at $70^{\circ} \mathrm{C}(4$ times of washing, $4 \mathrm{~mL}$ of $\alpha$-amylase was added in the previous 2 times). Thereafter, each sample was drowned in acetone for $10 \mathrm{~min}$, dried for another $10 \mathrm{~min}$, and finally dried in a dry oven at $60^{\circ} \mathrm{C}$ for $48 \mathrm{~h}$ before weighing. The obtained samples were put into the analyzer after determining NDF and ADF (Supplementary Tables 2-3). The analyzer machine was set with the above method (ANKOM, 2017). In short, washing was conducted twice without $\alpha$-amylase. Drowning in acetone was processed for $1 \mathrm{~min}$, followed by drying for $10 \mathrm{~min}$. Samples were weighted after drying in a drying oven at $60^{\circ} \mathrm{C}$ for $48 \mathrm{~h}$. The in-vitro NDF (IVNDFD) and ADF (IVADFD) degradation were calculated with the following formula: NDF/ADF $(\%)=$ (dried residue - [filter bag weight $\times \mathrm{C}]$ )/sample weight $\times 100$. Correction $(\mathrm{C})=$ dried blank bag weight / original blank bag weight. All the above samples were run in triplicate to increase the reliability of the assessment.

\section{Statistical analysis}

Data of exp. 1 are reported as samples least-squares means \pm standard deviation. Data were analyzed using the MIXED procedure of SAS program (version 9.1; SAS institute Inc., Cary, NC, USA) as a randomized completely block design. The model was:

$$
\mathrm{Yi}(\mathrm{t})=\mu+\mathrm{Ti}+\operatorname{Ei}(\mathrm{t})
$$

where $\mu$ was average value, Ti was treatment value, and $\operatorname{Ei}(t)$ was error value. The fixed effect was Gln level. Polynomial orthogonal contrasts were used to determine the fermentation effect using contrast (estimate) option. The value indicated least squares means. The differences between means were determined using Tukey post hoc test. Statistical difference was accepted at p-value less than 0.05 .

\section{RESULTS AND DISCUSSION}

\section{Experiment 1}

Ammonia- $\mathrm{N}$ concentrations were increased $(\mathrm{p}<0.001)$ over time when Gln was supplemented at $0.5 \%$ (Figure 1), indicating constant increase in Gln degradation by increasing incubation time from 0 to $48 \mathrm{~h}$. Ammonia-N concentration was increased between 6 and $24 \mathrm{~h}$, showing a peak at $36 \mathrm{~h}$. At $36 \mathrm{~h}$, ammonia-N concentration was $75.80 \mathrm{mg} / 100 \mathrm{~mL}$ greater in bottles containing Gln than those without Gln. A total of $100 \mathrm{mg} / 100 \mathrm{~mL}$ of ammonia-N was expected from complete degradation of $50 \mathrm{mM}$ Gln. Similar phenomenon in cattle supplemented with urea-molasses-mineral block was observed [22]. The mechanism behind increased ammonia- $\mathrm{N}$ concentration over time could be attributed to

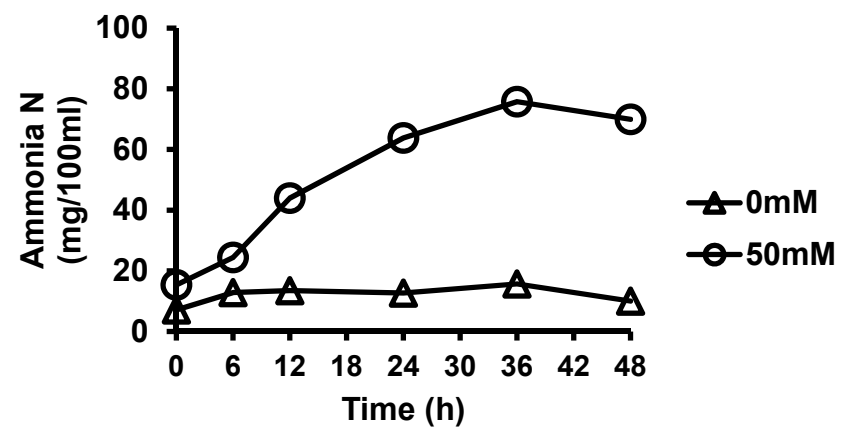

Figure 1. Ammonia $\mathrm{N}$ concentrations after in-vitro fermentation by ruminal bacteria in the group supplemented with $50 \mathrm{mM} \mathrm{L-glu-}$ tamine. Effects of incubation time were observed ( $p<0.001)$ (exp. 1).

deamination of the substrate (L-Gln) by rumen liquor microbes. Also, as expected, a steady concentration of ammonia$\mathrm{N}$ at $48 \mathrm{~h}$ after a peak at $36 \mathrm{~h}$ could be explained by a response to the balance between deamination and the utilization of ammonia- $\mathrm{N}$ by microbes, consistent with results of Wang et al [23] using limited AAs in-vitro. On the other hand, Gilbreath et al [24] stated that ruminal microbes of adult steers do not degrade extracellular L-citrulline and have a limited ability to metabolize extracellular L-Glu. The deamination occurs only during the short period of incubation.

The degradation rate by time was calculated based on the percentage of ammonia- $\mathrm{N}$ value at each incubation time when the maximum value was set at $36 \mathrm{~h}$ assuming $100 \%$ degradation. L-Gln degradation rate was $2 \%$ at $6 \mathrm{~h}, 21 \%$ at $12 \mathrm{~h}, 76 \%$ at $24 \mathrm{~h}$, and $100 \%$ at 36 to $48 \mathrm{~h}$. Given that the ruminal retention time was usually 12 to $24 \mathrm{~h}$ in case of powdery AAs, the present study showed degradation rates of approximately $21 \%$ to $76 \%$ (Table 4 ). Generally, degradation of AAs results in the amino group either being incorporated into other nitrogenous compounds or being excreted as ammonia or urea. Hence, an understanding of AA degradation provides insights on interrelationships between metabolic pathways and helps explain deficiencies in AA metabolism [25]. In this study, we observed a linear constant increase in degradation of L-Gln as time passed from $6 \mathrm{~h}$ to $36 \mathrm{~h}$ of incubation and then remained steady with a degradation rate of $100 \%$ at 36 to $48 \mathrm{~h}$. The degradation rate of Gln in the culture medium was $76 \%$, postulating the availability of two thirds of

Table 4. Calculated degradation rate of L-glutamine (exp. 1)

\begin{tabular}{lc}
\hline Time (h) & Degradation rate (\%) \\
\hline 6 & 2 \\
12 & 21 \\
24 & 76 \\
36 & 100 \\
48 & 100 \\
\hline
\end{tabular}

Degradation rate $=(36 \mathrm{~h}$ ammonia $\mathrm{N}-0 \mathrm{~h}$ ammonia- $\mathrm{N}) /(\mathrm{X} \mathrm{h}$ ammonia-N -0 h ammonia-N) $\times 100$. 
Gln by rumen microbes before digesta may be bypassed (in $24 \mathrm{~h}$ ) from the rumen based of the obtained result. Thus, attention is required about supplementation of Gln to the diet in future in-vivo studies. The rest of degradation may occur in the intestine in an actual animal study.

\section{Experiment 2}

This is the first study that tests several incubation times from 0 to $48 \mathrm{~h}$ with five levels of $\mathrm{L}-\mathrm{Gln}$ supplementation $(0 \%, 0.5 \%$, $1 \%, 2 \%$, and $3 \%$ ), and the contrast of L-Gln including linear and quadratic effects at once. Thus, fluctuations in results would be inevitable. Given this, it might be difficult to set only one level of supplementation as a final result. Also, the fact that feed usually will maintain in the rumen for about $24 \mathrm{~h}$, any recommendations should consider this average feed remaining time that can fluctuate by feed type and ingredients. Therefore, we provided a sectional conclusion based on each supplemental level for each trait before drawing an overall conclusion.

The $\mathrm{pH}$ range of the culture medium was reduced from 6.78 to 6.03 as the incubation time elapsed. There was a significant difference in the $\mathrm{pH}$ value of each treatment regardless of incubation time $(\mathrm{p}<0.05)$ (Table 5). The suitable range of $\mathrm{pH}$ value in rumen liquor is about 5.5 to 7.5 for microbial growth purpose. Any change in its $\mathrm{pH}$ can strongly affect the vigor of rumen microbes and their activity [23]. When the $\mathrm{pH}$ value is more than 7 , utilization of ammonia is reduced [12]. Meanwhile, when the $\mathrm{pH}$ value is less than 6.2, the degradation activity of cellulose is decreased, causing slower degradation of cellulose wall, lower growth of microorganisms, and lower production of VFAs and methane $[25,26]$. In addition, microorganisms might be inactivated when the $\mathrm{pH}$ is 5 or lower. The non-protein nitrogen fraction of feed is rich in Gln and other components. Consequently, it is likely that the add-up effects of L-Gln supplementation in this study can facilitate buffering capacity in the rumen as reported by general feature of some other AAs effects [27]. Accordingly, in this study, using L-Gln supplementation in culture medium could maintain $\mathrm{pH}$ within optimal values. Results of this study suggest that changes in $\mathrm{pH}$ depending on treatment were significantly different. However, all samples maintained $\mathrm{pH}$ values within its normal range, suggesting that L-Gln might not affect rumen fermentation in future invivo study. However, this result should be interpreted with caution before performing any actual in-vivo study due to effects of other feed ingredients on $\mathrm{pH}$ values. Although the $\mathrm{pH}$ range in this study was fairly consistent with the study of Zhang et al [18] that reported effects of branched chain AAs supplementation including valine, leucine, and isoleucine on in-vitro ruminal fermentation, their study showed unchanged

Table 5. Effects of L-glutamine supplementation levels on $\mathrm{pH}$, total gas, and ammonia-N concentration

\begin{tabular}{|c|c|c|c|c|c|c|c|c|c|c|}
\hline \multirow{2}{*}{ Items } & \multirow{2}{*}{ Time $(h)^{1)}$} & \multicolumn{5}{|c|}{ Treatments (\%) } & \multirow{2}{*}{ SEM } & \multicolumn{3}{|c|}{ p-value } \\
\hline & & Control & 0.5 & 1 & 2 & 3 & & Diet & Linear & Quadratic \\
\hline \multirow[t]{7}{*}{$\mathrm{pH}$} & 0 & $6.74^{\mathrm{b}}$ & $6.78^{a}$ & $6.68^{c}$ & $6.69^{c}$ & $6.69^{c}$ & 0.006 & $<0.001$ & $<0.001$ & $<0.001$ \\
\hline & 3 & $6.73^{\mathrm{a}}$ & $6.70^{\mathrm{ab}}$ & $6.67^{c}$ & $6.70^{b}$ & $6.67^{c}$ & 0.005 & $<0.001$ & $<0.001$ & 0.014 \\
\hline & 6 & $6.53^{\mathrm{a}}$ & $6.51^{\mathrm{ab}}$ & $6.47^{\mathrm{c}}$ & $6.52^{\mathrm{a}}$ & $6.49^{b c}$ & 0.006 & $<0.001$ & 0.003 & 0.012 \\
\hline & 12 & $6.28^{a}$ & $6.30^{\mathrm{a}}$ & $6.20^{\mathrm{b}}$ & $6.22^{b}$ & $6.23^{b}$ & 0.007 & $<0.001$ & $<0.001$ & $<0.001$ \\
\hline & 24 & $6.15^{\mathrm{a}}$ & $6.16^{\mathrm{a}}$ & $6.06^{b}$ & $6.07^{b}$ & $6.08^{b}$ & 0.005 & $<0.001$ & $<0.001$ & $<0.001$ \\
\hline & 36 & $6.14^{\mathrm{a}}$ & $6.16^{\mathrm{a}}$ & $6.05^{c}$ & $6.09^{b}$ & $6.07^{\mathrm{bc}}$ & 0.006 & $<0.001$ & $<0.001$ & $<0.001$ \\
\hline & 48 & $6.13^{b}$ & $6.17^{\mathrm{a}}$ & $6.03^{d}$ & $6.06^{\mathrm{c}}$ & $6.04^{\mathrm{cd}}$ & 0.006 & $<0.001$ & $<0.001$ & $<0.001$ \\
\hline \multirow[t]{6}{*}{ Total gas (mL) } & 3 & $0.17^{\mathrm{b}}$ & $2.33^{\mathrm{a}}$ & $1.17^{\mathrm{ab}}$ & $1.00^{\mathrm{ab}}$ & $0.67^{b}$ & 0.291 & 0.004 & 0.907 & 0.704 \\
\hline & 6 & $12.83^{b}$ & $15.33^{\mathrm{a}}$ & $12.58^{\mathrm{bc}}$ & $11.08^{\mathrm{c}}$ & $12.25^{\mathrm{bc}}$ & 0.367 & $<0.001$ & 0.421 & 0.828 \\
\hline & 12 & 23.25 & 23.58 & 23.33 & 22.83 & 23.50 & 0.242 & 0.284 & 0.975 & 0.904 \\
\hline & 24 & 38.33 & 38.67 & 37.00 & 35.33 & 38.67 & 1.578 & 0.533 & 0.785 & 0.301 \\
\hline & 36 & $64.67^{a}$ & $49.33^{\mathrm{ab}}$ & $48.67^{\mathrm{ab}}$ & $43.33^{b}$ & $53.67^{\mathrm{ab}}$ & 3.921 & 0.018 & $<0.001$ & $<0.001$ \\
\hline & 48 & $77.33^{\mathrm{a}}$ & $68.67^{\mathrm{ab}}$ & $56.67^{\mathrm{bc}}$ & $48.00^{c}$ & $47.33^{c}$ & 3.664 & $<0.001$ & $<0.001$ & $<0.001$ \\
\hline \multirow{7}{*}{$\begin{array}{l}\text { Ammonia-N } \\
\quad(\mathrm{mg} / 100 \mathrm{~mL})\end{array}$} & 0 & $5.73^{c}$ & $7.01^{b}$ & $7.92^{b}$ & $9.30^{a}$ & $8.86^{\mathrm{ab}}$ & 0.302 & 0.004 & 0.233 & 0.38 \\
\hline & 3 & $7.32^{b}$ & $7.59^{b}$ & $7.36^{b}$ & $7.89^{\mathrm{ab}}$ & $8.23^{a}$ & 0.166 & 0.035 & 0.684 & 0.873 \\
\hline & 6 & $5.30^{c}$ & $3.93^{d}$ & $5.90^{\mathrm{ab}}$ & $6.21^{a}$ & $6.44^{\mathrm{ab}}$ & 0.299 & $<0.001$ & 0.161 & 0.352 \\
\hline & 12 & $3.75^{d}$ & $4.18^{c d}$ & $4.19^{c}$ & $5.40^{\mathrm{a}}$ & $6.33^{a}$ & 0.090 & $<0.001$ & 0.04 & 0.705 \\
\hline & 24 & $7.76^{c}$ & $7.83^{c}$ & $8.28^{b}$ & $9.93^{\mathrm{a}}$ & $11.43^{\mathrm{a}}$ & 0.130 & $<0.001$ & 0.015 & 0.635 \\
\hline & 36 & 14.64 & 13.48 & 14.29 & 14.73 & 16.37 & 0.872 & 0.631 & 0.548 & 0.598 \\
\hline & 48 & 19.98 & 19.79 & 19.66 & 22.27 & 22.83 & 1.597 & 0.472 & 0.003 & 0.002 \\
\hline
\end{tabular}

The value indicate least squares means $(n=3)$.

SEM, standard error of the mean.

1) Time, incubation time.

2) Treatments: control (0\%), $0.5 \%, 1 \%, 2 \%$, and 3\% L-glutamine dry matter basis.

${ }^{a-d}$ The values with different superscripts in the same row differ significantly $(p<0.05)$ 
$\mathrm{pH}$ as provision amount was increased from 0 to $2,4,7$, and $10 \mathrm{mmol} / \mathrm{L}$. From a pH perspective, no restriction in L-Gln supplementation up to $3 \%$ can be considered.

Generally, total gas production per incubation time tended to decrease in all groups compared to the control groups except for the 3\% Gln group at $36 \mathrm{~h}$. On the other hand, total gas production tended to increase in all treatment groups with increasing incubation time. In particular, from $36 \mathrm{~h}$ to $48 \mathrm{~h}$ of incubation, Gln treated group showed a decrease $(\mathrm{p}<0.01)$ of total gas production compared to the control group while diet, linear, and quadratic effects were all significant. Higher $(\mathrm{p}<0.001)$ total gas in the $0.5 \%$ Gln group at 3 and $6 \mathrm{~h}$ compared to the control revealed that at early incubation time, $0.5 \% \mathrm{~L}$-Gln could cause an increase in total gas production which was supported by observing higher total VFA production at the same time of incubation (Table 6). When treatment groups were compared, the 3\% Gln level group showed the lowest gas production at $48 \mathrm{~h}$ (Table 5). Generally, total gas production, VFA production, and degradability are positively correlated with each other. Higher in-vitro total gas production reveals higher fermentation end products that could be preferable [11]. Total gas results can also be estimated from molar percentage of VFA $[12,28]$. Protein and starch are digested by microorganisms such as bacteria, protozoa, and fungi to produce sugar and AAs. Sugar and AAs sourced from diet or by microbial metabolism are digested by microorganisms again and then fermented VFA, $\mathrm{H}_{2}$, and $\mathrm{CO}_{2}$. In this study, the inhibitory effect of LGln supplementation at a high dosage ( $2 \%$ to $3 \%$, Table 5 ) to the culture medium on total gas production can be explained by a decrease of hydrogen supply for methanogens [12,29]. Janssen [30] explained the influence of hydrogen on rumen $\mathrm{CH}_{4}$ formation and fermentation balances through microbial growth kinetics and fermentation thermodynamics. Janssen [30] stated that hydrogen gas produced during microbial fermentation of feed is used as an energy source by methanogenic archaea (i.e., methanogens), which produce $\mathrm{CH}_{4}$. Therefore, in this study, Gln was competing with methane to use hydrogen in light of increase in propionic acid (Table 6) as supplementation rate of Gln increased. Given the above discussion and as $\mathrm{CH}_{4}$ is one component of total gas produced, $\mathrm{CH}_{4}$ production might be decreased by Gln supplementation. Most of the supplemented Gln might be transformed to Glu via GS-GOGAT pathway which is a dominant pathway for the ammonium assimilation in rumen bacterial ecology [31]. According to the pathway, when Gln is transformed to Glu, one molecule of nicotinamide adenine dinucleotide phosphate (NADPH) is used [31]. Various Glu fermentation pathways were reported, and a few pathways consume $\mathrm{H}^{+}$which is also the substrate for the methanogenesis $[32,33]$. As such, the Gln supplementation can reduce total gas production (TGP) not only because of the NADPH consumption during the GS-GOGAT pathway, but also the competition between Gln (or Glu) utilizing bacteria (e.g., Clostrkiium aminophilum, which is one of the most ammonia-producing rumen bacteria prefer Glu and Gln as a carbon source) and methanogens for hydrogen $[30,32,33]$. Therefore, Gln supplementation can promote protein synthesis and propionate production (Table 6) and decrease $\mathrm{CH}_{4}$ formation as propionate can compete with $\mathrm{CH}_{4}$ for hydrogen [28,30,31]. Furthermore, protozoa can affect activities of some methanogens [12], contributing about 10 to $25 \%$ of ruminal $\mathrm{CH}_{4}$ production [34]. However, the reason why L-Gln could not significantly alleviate total gas in mid incubation time of 12 and $24 \mathrm{~h}$ to the authors remained unclear. One hypothesis is that the ruminal fermentation process is inefficient because it produces some final products such as methane gas [35] and excess ammonia [36]. Consistently with the present results, Megías et al [37] have examined in-vitro gas production by supplementing by-products and indicated that highly $\mathrm{N}$ enriched substrates produce less gas than substrates with lower N. This was also confirmed in the present study. Depending on such hypothesis, if higher gas production is targeted, due to increasing incubation time, control and up to $1 \% \mathrm{~L}-\mathrm{Gln}$ supplementation can be considered for future in-vivo research. Vice versa, if mitigation of gas production is targeted, higher levels of L-Gln up to $3 \%$ is preferable. Therefore, setting an optimal level of L-Gln supplementation in order to affect total gas production depends on the aim of each study. In the present in-vitro study, since higher total gas production is associated with higher VFA production, control and $0.5 \%$ L-Gln supplementations in early incubation time can be studied in future research. Collectively, as the level of Gln increases, it has a negative (reduced) effect on total gas production. This should be considered in further in-vivo study.

Ammonia-N tended to increase in control and all treatment groups with increasing incubation time. The concentration of ammonia-N increased $(\mathrm{p}<0.05)$ with increasing L-Gln level at $48 \mathrm{~h}$ of incubation, showing both linear and quadratic effects (Table 5). Mainly, the highest ammonia-N concentrations were observed in groups with 2\% and 3\% L-Gln supplementations. Ammonia-N concentration is also considered as a colligation indicator of degradation and utilization of nitrogen source by rumen microbes [23]. When the activity of microorganisms in the rumen is increased, ammonia$\mathrm{N}$ is produced as $\mathrm{CP}$ and $\mathrm{AA}$ in the feed are decomposed. Degraded ammonia- $\mathrm{N}$ is used for microbial protein formation [11]. Crude protein content in feed is known to affect ammonia-N concentration [38]. The optimal ammonia- $\mathrm{N}$ concentration for microbial protein synthesis is somewhat different, ranging from $5 \mathrm{mg} / 100 \mathrm{~mL}$ to $29 \mathrm{mg} / 100 \mathrm{~mL}$. In addition, when ammonia- $\mathrm{N}$ concentration was greater than $84 \mathrm{mg} / 100 \mathrm{~mL}$, the capacity of liver reached its limit in the 
Table 6. Effects of L-glutamine supplementation levels on acetate, propionate, isobutyrate, butyrate, isovalerate, valerate, and total volatile fatty acids concentrations

\begin{tabular}{|c|c|c|c|c|c|c|c|c|c|c|}
\hline \multirow{2}{*}{ Items } & \multirow{2}{*}{ Time $(\mathbf{h})^{1)}$} & \multicolumn{5}{|c|}{ Treatments (\%) } & \multirow{2}{*}{ SEM } & \multicolumn{3}{|c|}{ p-value } \\
\hline & & Control & 0.5 & 1 & 2 & 3 & & Diet & Linear & Quadratic \\
\hline \multirow{4}{*}{$\begin{array}{r}\text { Acetate } \\
(\mathrm{mM})\end{array}$} & 0 & 18.80 & 18.90 & 18.68 & 18.98 & 18.86 & 0.070 & 0.651 & 0.904 & 0.984 \\
\hline & 6 & $38.14^{b}$ & $41.80^{\mathrm{a}}$ & $38.26^{b}$ & $37.32^{b}$ & $38.34^{\mathrm{b}}$ & 0.274 & 0.002 & 0.041 & 0.841 \\
\hline & 12 & $53.63^{b}$ & $55.26^{b}$ & $55.38^{b}$ & $56.81^{\mathrm{ab}}$ & $59.16^{a}$ & 0.378 & 0.005 & $<0.001$ & 0.724 \\
\hline & 24 & $70.24^{\mathrm{bc}}$ & $70.41^{\mathrm{bc}}$ & $68.04^{c}$ & $71.30^{b}$ & $74.43^{\mathrm{a}}$ & 0.332 & $<0.001$ & $<0.001$ & $<0.001$ \\
\hline \multirow{5}{*}{$\begin{array}{l}\text { Propionate } \\
\quad(\mathrm{mM})\end{array}$} & 0 & 3.45 & 3.46 & 3.40 & 3.44 & 3.43 & 0.027 & 0.652 & 0.906 & 0.984 \\
\hline & 3 & $6.55^{b}$ & $7.51^{\mathrm{a}}$ & $6.31^{b}$ & $6.50^{\mathrm{b}}$ & $6.71^{b}$ & 0.110 & 0.003 & 0.473 & 0.253 \\
\hline & 6 & $10.88^{c}$ & $11.74^{\mathrm{a}}$ & $11.42^{b}$ & $10.67^{\circ}$ & $10.55^{c}$ & 0.106 & 0.002 & 0.042 & 0.841 \\
\hline & 12 & $15.08^{c}$ & $15.38^{\mathrm{C}}$ & $16.81^{a}$ & $16.29^{b}$ & $16.17^{b}$ & 0.146 & 0.005 & $<0.001$ & 0.723 \\
\hline & 24 & $18.97^{\mathrm{C}}$ & $18.94^{\mathrm{C}}$ & $19.65^{a}$ & $18.96^{\circ}$ & $19.58^{\mathrm{ab}}$ & 0.128 & $<0.001$ & $<0.001$ & $<0.001$ \\
\hline \multirow{5}{*}{$\begin{array}{l}\text { Isobutyrate } \\
(\mathrm{mM})\end{array}$} & 6 & $0.14^{\mathrm{a}}$ & $0.14^{\mathrm{a}}$ & $0.13^{b}$ & $0.13^{b}$ & $0.13^{b}$ & 0.002 & $<0.001$ & 0.003 & 0.103 \\
\hline & 12 & 0.18 & 0.18 & 0.17 & 0.18 & 0.18 & 0.005 & 0.194 & 0.442 & 0.028 \\
\hline & 24 & $0.30^{a}$ & $0.30^{a}$ & $0.26^{b}$ & $0.28^{a}$ & $0.30^{a}$ & 0.005 & $<0.001$ & 0.905 & $<0.001$ \\
\hline & 36 & $0.39^{a}$ & $0.39^{\mathrm{ab}}$ & $0.34^{d}$ & $0.37^{b c}$ & $0.36^{\mathrm{cd}}$ & 0.007 & $<0.001$ & $<0.001$ & $<0.001$ \\
\hline & 48 & $0.43^{a}$ & $0.43^{a}$ & $0.39^{b}$ & $0.41^{\mathrm{a}}$ & $0.42^{a}$ & 0.005 & $<0.001$ & 0.174 & $<0.001$ \\
\hline \multirow{6}{*}{$\begin{array}{c}\text { Butyrate } \\
\text { (mM) }\end{array}$} & 0 & 1.54 & 1.55 & 1.50 & 1.54 & 1.53 & 0.010 & 0.063 & 0.989 & 0.836 \\
\hline & 3 & $2.31^{b}$ & $2.63^{a}$ & $2.04^{c}$ & $2.27^{\mathrm{bc}}$ & $2.46^{\mathrm{ab}}$ & 0.049 & $<0.001$ & 0.780 & 0.014 \\
\hline & 6 & $3.58^{\mathrm{abc}}$ & $3.84^{a}$ & $3.35^{c}$ & $3.46^{\mathrm{bc}}$ & $3.68^{\mathrm{ab}}$ & 0.052 & 0.001 & 0.767 & 0.014 \\
\hline & 12 & $5.79^{c}$ & $5.70^{c}$ & $5.82^{c}$ & $6.34^{b}$ & $6.78^{a}$ & 0.083 & $<0.001$ & $<0.001$ & 0.005 \\
\hline & 24 & $7.64^{\mathrm{bc}}$ & $7.35^{\mathrm{cd}}$ & $7.11^{d}$ & $7.84^{b}$ & $8.36^{a}$ & 0.064 & $<0.001$ & $<0.001$ & $<0.001$ \\
\hline & 36 & $8.20^{a}$ & $7.98^{\mathrm{ab}}$ & $7.56^{b}$ & $8.29^{a}$ & $8.47^{a}$ & 0.107 & 0.003 & $<0.001$ & $<0.001$ \\
\hline $\begin{array}{l}\text { Isovalerate } \\
\quad(\mathrm{mM})\end{array}$ & 48 & $0.71^{a}$ & $0.71^{a}$ & $0.63^{b}$ & $0.68^{a}$ & $0.70^{a}$ & 0.011 & $<0.001$ & $<0.001$ & 0.007 \\
\hline \multirow{7}{*}{$\begin{array}{c}\text { Valerate } \\
\text { (mM) }\end{array}$} & 0 & 0.10 & 0.10 & 0.10 & 0.10 & 0.10 & 0.002 & 0.384 & 0.794 & 0.936 \\
\hline & 3 & $0.17^{\mathrm{ab}}$ & $0.19^{a}$ & $0.15^{c}$ & $0.16^{b c}$ & $0.18^{\mathrm{ab}}$ & 0.007 & $<0.001$ & 0.784 & 0.003 \\
\hline & 6 & $0.31^{\mathrm{ab}}$ & $0.32^{a}$ & $0.28^{c}$ & $0.29^{b c}$ & $0.29^{b c}$ & 0.009 & 0.002 & 0.002 & 0.021 \\
\hline & 12 & 0.41 & 0.41 & 0.42 & 0.43 & 0.43 & 0.012 & 0.168 & 0.002 & 0.501 \\
\hline & 24 & $0.53^{\mathrm{ab}}$ & $0.53^{\mathrm{ab}}$ & $0.51^{c}$ & $0.52^{\mathrm{bc}}$ & $0.55^{\mathrm{a}}$ & 0.009 & 0.002 & 0.012 & $<0.001$ \\
\hline & 36 & $0.61^{a}$ & $0.60^{a}$ & $0.56^{b}$ & $0.59^{\mathrm{ab}}$ & $0.58^{\mathrm{ab}}$ & 0.013 & 0.004 & 0.007 & $<0.001$ \\
\hline & 48 & $0.62^{a}$ & $0.62^{a}$ & $0.58^{b}$ & $0.62^{a}$ & $0.64^{a}$ & 0.011 & 0.002 & 0.002 & $<0.001$ \\
\hline \multirow{7}{*}{$\begin{array}{c}\text { Total VFA } \\
(\mathrm{mM})\end{array}$} & 0 & 24.07 & 24.19 & 23.89 & 24.24 & 24.11 & 0.110 & 0.790 & 0.928 & 0.963 \\
\hline & 3 & $35.86^{b}$ & $40.41^{a}$ & $33.99^{b}$ & $35.62^{b}$ & $36.87^{\mathrm{ab}}$ & 0.461 & 0.002 & 0.553 & 0.156 \\
\hline & 6 & $53.26^{b}$ & $58.05^{a}$ & $53.64^{b}$ & $52.07^{b}$ & $53.19^{b}$ & 0.440 & 0.002 & 0.059 & 0.55 \\
\hline & 12 & $75.38^{b}$ & $77.20^{\mathrm{b}}$ & $78.85^{b}$ & $80.33^{\mathrm{ab}}$ & $82.99^{a}$ & 0.626 & 0.003 & $<0.001$ & 0.473 \\
\hline & 24 & $98.15^{\mathrm{bc}}$ & $97.99^{\mathrm{bc}}$ & $95.98^{c}$ & $99.34^{b}$ & $103.7^{\mathrm{a}}$ & 0.531 & $<0.001$ & $<0.001$ & $<0.001$ \\
\hline & 36 & $107.0^{\mathrm{a}}$ & $105.9^{\mathrm{ab}}$ & $101.8^{b}$ & $105.8^{\mathrm{ab}}$ & $107.0^{\mathrm{a}}$ & 0.743 & 0.021 & 0.226 & $<0.001$ \\
\hline & 48 & $106.8^{b c}$ & $107.0^{\mathrm{bc}}$ & $105.6^{c}$ & $109.2^{\mathrm{ab}}$ & $112.0^{\mathrm{a}}$ & 0.477 & $<0.001$ & $<0.001$ & 0.003 \\
\hline
\end{tabular}

The value indicate least squares means $(n=3)$.

SEM, standard error of the mean; VFA, volatile fatty acids.

1) Time, incubation time.

2) Treatments: control (0\%), $0.5 \%, 1 \%, 2 \%$, and $3 \%$ L-glutamine dry matter basis.

a-d The values with different superscripts in the same row are differ significantly $(p<0.05)$. 
treatment group and poisoning symptoms appeared within 30 minutes after feeding [39]. In our study, concentrations of ammonia- $\mathrm{N}$ in all treatment group were lower than its toxic level. However, $2 \%$ and 3\% Gln groups had the highest concentrations of ammonia-N while the $0.5 \%$ Gln group had lower concentration of ammonia- $\mathrm{N}$ than the control group. The results of exp. 2 are consistent with the results of exp. 1, indicating that ammonia- $\mathrm{N}$ concentration was increased with increasing incubation time. However, in an actual in-vivo study, higher concentrations of ammonia-N should be avoided due to possible toxicity effects. Thus, $2 \%$ and 3\% L-Gln might need to be avoided. Higher concentration of ammonia-N in $2 \%$ and $3 \%$ groups may also imply the inability of microorganisms to use Gln when the higher synthesis of protein is targeted. This phenomenon could be due to an unequal availability of energy and ammonia, making them less useful in the process of microbial protein synthesis as suggested by Syamsi et al [11] after supplementing various meal protein sources with different protein-energy synchronization index in dairy ration. In the present study, the low and high values of ammonia-N concentration fell within its suitable range in culture medium in both experiments (Figure 1; Table 5).

In the present study, acetate, propionate, and total VFA tended to increase with elevated Gln level and incubation time, particularly from 12 to $48 \mathrm{~h}(\mathrm{p}<0.001)$ (Tables 6,7$)$. Principally, acetate showed quadratic effects with maximum amounts in control, $0.5 \%, 2 \%$, and 3\% L-Gln supplementation whereas propionate showed higher amounts mainly in $0.5 \%$ and $1 \% \mathrm{~L}-$ Gln groups. This increase is in line with the result of exp. 1 showing an increased degradation rate of LGln over time. Thus, degradation of L-Gln could provide a good substrate for VFA production. Microorganisms are known to grow and develop by utilizing feed substrates and producing VFAs. Improving the performance of rumen microorganisms will be in line with increasing rumen fermentation products, ultimately increasing the productivity of the animals [11]. VFAs are the end products of ruminal microbial fermentation. They are used as major sources of ruminant metabolism energy [27]. Main VFAs that are targeted to increase include acetate and propionate rather than branched chain VFAs that are present in total VFA in very small amounts. Acetate is used for fat synthesis. Propionate is known to be used for gluconeogenesis. Gln is temperature sensitive. It can be transformed into Glu within the rumen and used as a precursor for Glu and alanine in the skeletal muscle. Gln and alanine pathways produce acetate and propionate [39]. Taken together, these results indicate that increasing concentration of L-Gln can increase VFA production. Obtained results are consistent with results of Zain et al [40] in-vivo on sheep and Zhang et al [14] in-vitro, reporting increased acetate, propionate, and total of branched chain VFA by supplementing branched chain AAs. The reason for this increase may be due to expedition of L-Gln substrate degradation. Syamsi et al [11] have stated the role of cellulolytic bacteria in inducing the production of VFAs, with acetic acid as a corresponding VFA to digest structural carbohydrate. Another reason for higher acetate concentration in the $0.5 \%$ Gln group could be attributed to the higher fiber degradability including NDF and ADF in the same group. These results suggest that L-Gln should be supplemented to ruminants at $0.5 \%$ in further in-vivo studies. In this study, total VFAs and individual VFAs yielded more quadratic increases, particularly by increasing incubation time from $24 \mathrm{~h}$ to $48 \mathrm{~h}$ as supplementation amount of LGln increased. The lowest amount of VFAs was produced when L-Gln supplementation was set at $1 \%$ level. This phenomenon could be explained by congestion of VFAs by increasing supplementation of L-Gln from $0.5 \%$ to $1 \%$. However, the quadratic increase when Gln supplementation was set at $2 \%$ and $3 \%$ levels remained unclear. One hypothesis could be that branched chain VFAs including isobutyric, isovaleric, and 2-methylbutyric acid are produced due to forage fiber degradation by microorganisms and degradation of branched chain AAs including valine, leucine, and isoleucine $[17,18]$ in the rumen primarily originating from dietary true protein degradation [18] (herein, L-Gln). Furthermore, branched chain VFA is a result of AA deamination in the rumen. Therefore, an increase in branched chain VFA level in the rumen can be induced by supplementing high protein source in the ration [41], herein L-Gln. Isobutyrate and butyrate followed similar pattern of alterations in culture medium (Table 6). Comparable significant values where at least diet effect was accompanied by either linear or quadratic effects except for isobutyrate at $12 \mathrm{~h}$ were observed from $3 \mathrm{~h}$ to $48 \mathrm{~h}$, whereas $1 \% \mathrm{~L}-\mathrm{Gln}$ supplementation showed the lowest values of butyrate and isobutyrate. Isovalerate and valerate concentrations showed exactly the same pattern of alterations as butyrate and isobutyrate, respectively. Given positive effects of L-Gln after different incubation time on acetate at 0.5 and $2 \%$ to $3 \%$ levels of Gln and propionate at both $0.5 \%$ and $1 \%$ levels of Gln in-vitro, recommendation of the optimum level of Gln supplementation should be obtained with caution in order to obtain desired VFAs prior to actual in-vivo studies. However, most of significant higher values in each VFA were observed in the $0.5 \% \mathrm{~L}-\mathrm{Gln}$ supplementation group. With respect to the concentrations of other branched chain VFAs, the optimum level of Gln supplementation could be set at both $0.5 \%$ and $3 \%$ considering results of the present study. Since lower amount of any supplemented product is desirable economically, provision of $0.5 \% \mathrm{~L}-\mathrm{Gl}$ could be the best choice. However, this level should be confirmed in further in-vivo studies. 
Degradability results are provided in Table 7. Control and $0.5 \%$ group after all incubation time, $1 \%$ group after up to $24 \mathrm{~h}$ incubation, and $2 \%$ group after $12 \mathrm{~h}$ incubation showed the highest degradability of DM with a quadratic effect $(p<0.001)$. NDF degradability showed fluctuations from time to time, whereas it achieved the maximum values when L-Gln was added at $2 \%$ after $12 \mathrm{~h}$ incubation, $0.5 \%$ and $1 \%$ after $24 \mathrm{~h}$ incubation, and $0.5 \%$ and control after $48 \mathrm{~h}$ of incubation, showing a quadratic effect $(\mathrm{p}=0.005)$. Similar pattern was obtained in ADF degradability while $0.5 \%$ and $3 \% \mathrm{~L}-\mathrm{Gln}$ supplementation after $48 \mathrm{~h}$ of incubation showed quadratic effect $(p=0.003)$. L-Gln also increased CP degradability $(\mathrm{p}<0.001)$, with the highest degradability found in the 3\% L-Gln group regardless of incubation time $(p<0.05)$. Degradability of DM rely on the rate of AA supplementation. In this study, DM degradability was declined when the level of added L-Gln exceeded 2\%. Using branched chain AAs supplementation in-vitro, consistent decline in DM digestibility was observed when the level of supplementation exceeded $2 \mathrm{mmol} / \mathrm{L}$ [18]. Although 1\% Gln group after 12 and $24 \mathrm{~h}$ of incubation and 2\% Gln group after 12 $\mathrm{h}$ of incubation showed similar DM degradability as the 0.5\% Gln group, the $0.5 \%$ Gln group showed higher DM degradability regardless of incubation time, revealing a constant influence of L-Gln supplementation at the corresponding level. Higher DM degradability after all incubation time were observed in the $0.5 \%$ Gln group, indicating that the optimal concentration of L-Gln for digestion by rumi- nal microorganisms should be approximately $0.5 \%$. Yang et al [42] have reported the paucity of information regarding the effects of adding branched chain AAs on ruminal fermentation characteristics both in-vitro and in-vivo. In the present study, although fluctuations in NDF degradability were observed among incubation time, higher degradability of NDF was found in the $0.5 \%$ Gln group after 24 to $48 \mathrm{~h}$ incubation, the $1 \%$, Gln group after $24 \mathrm{~h}$ incubation, and the $2 \%$ Gln group after $12 \mathrm{~h}$ incubation, indicating that ruminal microorganisms in culture medium could benefit from direct supplementation of L-Gln when the supplementation level was decreased from $2 \%$ to $0.5 \%$ and when the incubation time was increased. Consistent with our results for low level of L-Gln supplementation (0.5\%), Zhang et al [18] have reported higher degradability of NDF when valine and isoleucine are supplemented at low concentration of $2 \mathrm{mmol} / \mathrm{L}$ compared to 4,7 , and $10 \mathrm{mmol} / \mathrm{L}$ levels. This was also reported by Chen et al [43]. Similar pattern in increasing NDF degradability by ascending incubation time and descending L-Gln level was also observed in ADF degradability. The reason behind a sudden quadratic increase in ADF degradability in the $3 \%$ group at $48 \mathrm{~h}$ remains uncertain. However, decreased NDF and ADF degradabilities in $1 \%$ and $2 \%$ groups at $48 \mathrm{~h}$ after observing their increases in the group with $0.5 \%$ Gln supplementation might be explained by saturation of culture medium between the ratio of supplementation and activity of microorganisms for fiber fraction degradation. These results revealed a balance be-

Table 7. Effects of L-glutamine supplementation levels on DM, NDF, ADF, and CP degradability

\begin{tabular}{|c|c|c|c|c|c|c|c|c|c|c|}
\hline \multirow{2}{*}{ Items } & \multirow{2}{*}{ Time $(h)^{1)}$} & \multicolumn{5}{|c|}{ Treatments $(\%)^{2)}$} & \multirow{2}{*}{ SEM } & \multicolumn{3}{|c|}{ p-value } \\
\hline & & Control & 0.5 & 1 & 2 & 3 & & Diet & Linear & Quadratic \\
\hline \multirow[t]{4}{*}{$\operatorname{DMD}(\%)$} & 0 & $5.69^{a}$ & $4.02^{a}$ & $4.71^{a}$ & $4.74^{a}$ & $5.25^{b}$ & 0.989 & 0.002 & 0.949 & 0.566 \\
\hline & 12 & $40.76^{\mathrm{C}}$ & $45.58^{\mathrm{ab}}$ & $46.04^{a}$ & $46.16^{a}$ & $40.88^{c}$ & 1.143 & 0.015 & 0.607 & 0.001 \\
\hline & 24 & $58.50^{d}$ & $66.36^{\mathrm{ab}}$ & $68.12^{\mathrm{a}}$ & $63.52^{b}$ & $61.46^{\mathrm{c}}$ & 1.199 & 0.003 & 0.831 & $<0.001$ \\
\hline & 48 & $69.93^{b c}$ & $75.44^{a}$ & $69.79^{c}$ & $65.64^{\mathrm{cd}}$ & $70.21^{b c}$ & 1.696 & 0.033 & 0.120 & 0.323 \\
\hline \multirow[t]{4}{*}{ NDFD (\% DM) } & 0 & 11.03 & 10.03 & 11.75 & 9.67 & 9.52 & 0.294 & 0.121 & 0.601 & 0.648 \\
\hline & 12 & 50.58 & 54.79 & 53.21 & 57.34 & 52.04 & 0.555 & 0.062 & 0.055 & 0.668 \\
\hline & 24 & 70.65 & 77.65 & 80.11 & 75.1 & 73.38 & 1.035 & 0.339 & 0.846 & 0.102 \\
\hline & 48 & $85.00^{\mathrm{ab}}$ & $86.88^{a}$ & $79.11^{c}$ & $78.35^{\mathrm{cd}}$ & $84.52^{b}$ & 1.577 & 0.025 & 0.682 & 0.005 \\
\hline \multirow[t]{4}{*}{ ADFD (\% DM) } & 0 & 10.59 & 9.99 & 11.79 & 10.10 & 12.65 & 0.223 & 0.697 & 0.207 & 0.222 \\
\hline & 12 & $48.18^{e}$ & $52.28^{\mathrm{bc}}$ & $50.95^{d}$ & $54.83^{a}$ & $52.63^{b}$ & 0.403 & 0.054 & 0.013 & 0.131 \\
\hline & 24 & 68.85 & 75.01 & 77.08 & 72.66 & 72.63 & 0.726 & 0.759 & 0.580 & 0.918 \\
\hline & 48 & $83.07^{\mathrm{ab}}$ & $84.83^{a}$ & $76.49^{c}$ & $74.59^{c}$ & $85.44^{a}$ & 1.053 & 0.014 & 0.435 & 0.003 \\
\hline \multirow[t]{4}{*}{ CPD (\% DM) } & 0 & 7.68 & 1.79 & 0.68 & 0.00 & 16.39 & 0.223 & 0.458 & 0.016 & 0.03 \\
\hline & 12 & $45.52^{c}$ & $51.94^{b}$ & $53.34^{\mathrm{a}}$ & $42.22^{e}$ & $44.00^{d}$ & 0.095 & 0.037 & 0.900 & 0.481 \\
\hline & 24 & $66.68^{c}$ & $77.73^{\mathrm{a}}$ & $76.63^{b}$ & $68.63^{c}$ & $65.53^{d}$ & 0.083 & 0.007 & 0.836 & 0.925 \\
\hline & 48 & $80.75^{b}$ & $87.46^{a}$ & $79.66^{c}$ & $68.81^{e}$ & $76.73^{d}$ & 0.063 & $<0.001$ & $<0.001$ & 0.922 \\
\hline
\end{tabular}

The value indicate least squares means $(n=3)$.

DM, dry matter; NDF, neutral detergent fiber; ADF, acid detergent fiber; CP, crude protein; DMD, degradability of dry matter; NDFD, degradability of neutral detergent fiber; ADFD, degradability of acid detergent fiber; CPD, degradability of crude fiber.

1) Time, incubation time.

2) Treatments: control (0\%), 0.5\%, 1\%, 2\%, and 3\% L-glutamine DM basis.

a-e The values with different superscripts in the same row are differ significantly $(p<0.05)$. 
tween supplementation rate and microorganism activity. Thus, $0.5 \% \mathrm{~L}-\mathrm{Gln}$ supplementation is suitable when fiber degradability is targeted. Consistently, Yang et al [42] have reported similar effects of direct provision of breached chain AAs on degradability of fiber fraction in-vitro. With regard to CP degradability, Ruminobacter amylophilus, Prevotella ruminicola, Butyrivibrio fibrisolven, Strptococcus bovis, and Peptostreptococcus are typical feed protein degradation bacteria that can grow using AAs and peptides. These bacteria account for more than $10 \%$ of digestive bacteria [42]. The growth of microorganisms is influenced by energy, ammonia, and cofactors. Energy and ammonia are main factors that are mutually limiting. Thus, means that an unequal availability of energy and ammonia would keep them less useful in the process of microbial protein synthesis [11]. Symasi et al [11] indicated that both ammonia and energy have to be available simultaneously (synchronous) to achieve maximum microbial protein production. Synchronized availability of energy and ammonia is influenced by the rate of degradation of protein (herein L-Gln) and carbohydrate degradation products as energy sources (herein VFAs). Hence, the reason behind higher degradability of CP in the $3 \% \mathrm{~L}-\mathrm{Gln}$ group can be attributed to the synchronization of L-Gln with substrate for maximizing bacteria growth. On the other hand, branched chain VFAs and total VFA can be used to estimate the degree of protein degradation [17] as shown in the present study. Another hypothesis that may explain higher CP degradability could be higher VFAs and ammonia- $\mathrm{N}$ in the corresponding group ( $3 \% \mathrm{~L}-\mathrm{Gln}$ ). Furthermore, higher ammonia- $\mathrm{N}$ is associated with lower microbial proteins due to saturation of microorganisms' inability of using excess $\mathrm{N}$ to produce microbial proteins as stated by Symasi et al [11]. Considering our degradability results, $0.5 \% \mathrm{~L}$-Gln supplementation could be beneficial to improve $\mathrm{DM}, \mathrm{CP}, \mathrm{ADF}$, and NDF degradability, although this should be confirmed in further in-vivo studies.

One limitation of this study was inconsistency in some results including VFA and gas production results. The inconsistent results might be resulted from the ice treatment during the in-vitro procedure. When the incubation bottles were taken from the shaking incubator, the bottles were put on the ice to stop the further microbial fermentation. But, the TGP measurements were conducted when the bottles were on the ice. Accordingly, the TGP decreased according to the decreased temperature of the headspace. Another limitation was regarding microbial activity analysis, which have not performed in this study. The reason for this was due to unavailability of previous study having several various levels of L-Gln supplementation with very wide range of incubation times. As such, microbial activity was not the first important criteria to be measured while no information was available with respect to the total gas production, L-Gln deg- radation, ammonia production, and VFA production etc. Thus, microbial activity should be further examined in future study after taking into account of the results of this study.

\section{CONCLUSION}

No toxicity was observed based on determined values of $\mathrm{pH}$ and ammonia-N (NH3) in all treatment groups after supplementation of L-Gln at high levels of $2 \%$ and $3 \%$ in-vitro. However, 2\% and 3\% L-Gln supplementation increased ammonia-N numerically which could potentially cause toxic effects in an actual in-vivo study. Thus, before making an overall decision of using high levels of supplementation, caution should be given over supplementation of $2 \%$ to $3 \% \mathrm{~L}$ Gln due to other influencing cofactors in the rumen in a further in-vivo study. Overall, the supplementation of L-Gln at $0.5 \%$ is recommended due to its positive effects on overall traits assessed including rumen fermentation end products (VFAs) and degradability of nutrients. Thus, $0.5 \%$ Gln should be tested in further in-vivo studies.

\section{CONFLICT OF INTEREST}

We certify that there is no conflict of interest with any financial organization regarding the material discussed in the manuscript.

\section{FUNDING}

This work was supported by Korean Institute of Planning and Evaluation for Technology in Food, Agriculture, Forestry and Fisheries (IPET) through (Export Promotion Technology Development Program), funded by Ministry of Agriculture, Food and Rural Affairs (MAFRA) (grant number 618002-05).

\section{REFERENCES}

1. Xiao D, Zeng L, Yao K, Kong X, Wu G, Yin Y. The glutaminealpha-ketoglutarate (AKG) metabolism and its nutritional implications. Amino Acids 2016;48:2067-80. https://doi. org/10.1007/s00726-016-2254-8

2. Shah AM, Wang Z, Ma J. Glutamine metabolism and its role in immunity, a comprehensive review. Animals 2020; 10:326. https://doi.org/10.3390/ani10020326

3. Antonio J, Street C. Glutamine: A potentially useful supplement for athletes. Can J Appl Physiol 1999;24:1-14. https:// doi.org/10.1139/h99-001

4. Kreider RB. Dietary supplements and the promotion of muscle growth with resistance exercise. Sports Med 1999;27:97-110. https://doi.org/10.2165/00007256-199927020-00003

5. Akbarnezhad A, Ravasi AA, Aminian Razavi TD, Nourmohammadi I. The effect of creatine and glutamine supplements 
on athletic performance in elite wrestlers after one acute period of weight losing. Harakat 2006;27:173-88.

6. Ramezani Ahmadi A, Rayyani E, Bahreini M, Mansoori A. The effect of glutamine supplementation on athletic performance, body composition, and immune function: A systematic review and a meta-analysis of clinical trials. Clin Nutr 2019; 38:1076-91. https://doi.org/10.1016/j.clnu.2018.05.001

7. Wu G. Amino acids: metabolism, functions, and nutrition. Amino Acids 2009;37:1-17. https://doi.org/10.1007/s00726009-0269-0

8. Wu G, Bazer FW, Johnson GA, et al. Triennial Growth Symposium: important roles for L-glutamine in swine nutrition and production. J Anim Sci 2011;89:2017-30. https://doi. org/10.2527/jas.2010-3614

9. Kim YS, Lee JS, Lee YS, et al. Effect of glutamine on heatshock protein beta 1 (HSPB1) expression during myogenic differentiation in bovine embryonic fibroblast cells. J Food Sci Biotechnol 2018;27:829-35. https://doi.org/10.1007/ s10068-018-0309-1

10.Lobley G, Hoskin S, McNeil CJ. Glutamine in animal science and production. J Nutr 2001;131:2525S-31S. https://doi.org/ 10.1093/jn/131.9.2525S

11.Syamsi AN, Waldi L, Widodo HS, Harwanto. Branched chain volatile fatty acids profile of rumen fluids supplemented by different meal protein sources and protein-energy synchronization index. IOP Conference Series: Earth Environ Sci 2019; 372:012060. https://doi.org/10.1088/1755-1315/372/1/012060

12. Kim JY, Ghassemi Nejad J, Park JY, et al. In vivo evaluation of garlic (Allium sativum) supplementation to rice strawbased diet on mitigation of $\mathrm{CH} 4$ and $\mathrm{CO} 2$ emissions and blood profiles using crossbreed rams. J Sci Food Agric 2018; 98:5197-204. https://doi.org/10.1002/jsfa.9055

13. Warner ACI. The breakdown of asparagine, glutamine, and other amides by microorganisms from the sheep's rumen. Aust J Biol Sci 1964;17:170-82. https://doi.org/10.1071/BI96 40170

14. Hoshino S, Sarumaru K, Morimoto K. Ammonia anabolism in ruminants. J Dairy Sci 1966,49:1523-8. https://doi.org/ 10.3168/jds.S0022-0302(66)88130-4

15. Chalupa W, Clark J, Opliger P, Lavker R. Ammonia metabolism in rumen bacteria and mucosa from sheep fed soy protein or urea. J Nutr 1970;100:161-9. https://doi.org/10.1093/jn/ 100.2.161

16. Moss AR, Jouany JP, Newbold J. Methane production by ruminants: Its contribution to global warming. Ann Zootech 2000;49:231-53. https://doi.org/10.1051/animres:2000119

17. Apajalahti J, Vienola K, Raatikainen K, Holder V, Moran CA. Conversion of branched-chain amino acids to corresponding isoacids - an in vitro tool for estimating ruminal protein degradability. Front Vet Sci 2019;6:311. https://doi.org/10. 3389/fvets.2019.00311

18.Zhang HL, Chen Y, Xu XL, Yang YX. Effects of branched- chain amino acids on in vitro ruminal fermentation of wheat straw. Asian-Australas J Anim Sci 2013,26:523-8. https://doi. org/10.5713/ajas.2012.12539

19. McDougall EI. Studies on ruminant saliva. 1. The composition and output of sheep's saliva. Biochem J 1948;43:99-109. https:// doi.org/10.1042/bj0430099

20. Chaney AL, Marbach EP. Modified reagents for determination of urea and ammonia. Clin Chem 1962;8:130-2. https://doi. org/10.1093/clinchem/8.2.130

21.Erwin ES, Marco GJ, Emery EM. Volatile fatty acid analyses of blood and rumen fluid by gas chromatography. J Dairy Sci 1961;44:1768-71. https://doi.org/10.3168/jds.S0022-0302 (61)89956-6

22. Srinivas B, Gupta BN. Rumen fermentation, bacterial and total volatile fatty acid (TVFA) production rates in cattle fed on urea-molasses-mineral block licks supplement. Anim Feed Sci Technol 1997;65:275-86. https://doi.org/10.1016/ S0377-8401(96)01062-0

23. Wang MZ, Wang HR, Cao HC, Li GX, Zhang J. Effects of limiting amino acids on rumen fermentation and microbial community in vitro. Agric Sci China 2008;7:1524-31. https:// doi.org/10.1016/S1671-2927(08)60412-5

24.Gilbreath KR, Nawaratna GI, Wickersham TA, Satterfield MC, Bazer FW, Wu G. Ruminal microbes of adult steers do not degrade extracellular L-citrolline and have limited ability to metabolize extracellular L-glutamate. J Anim Sci 2019;97: 3611-6. https://doi.org/10.1093/jas/skz227

25.Sawers RG. Amino acid degradation. eLS. Chichester, UK: John Wiley \& Sons Ltd.; 2015. pp. 1-11. https://chem.libretexts. org/@go/page/234048

26. Argyle JL, Baldwin RL. Effects of amino acids and peptides on rumen microbial growth yields. J Dairy Sci 1989;72:201727. https://doi.org/10.3168/jds.S0022-0302(89)79325-5

27.López S. In vitro and in situ techniques for estimating digestibility. In: Dijkstra J, Forbes JM, France J, editors. Quantitative aspects of ruminant digestion and metabolism. Wallingford, UK: CABI Publishing; 2005. pp. 87-121. https://doi.org/10. 1079/9780851998145.0049

28. Van Soest PJ. Nutritional ecology of the ruminant. 2nd edn. NY, USA: Cornell University Press; 1994. https://www.jstor. org/stable/10.7591/j.ctv5rf668

29. Anassori E, Dali-Naghadeh B, Pirmohammadi R, Hadian M. Changes in blood profile in sheep receiving raw garlic, garlic oil or monensin. J Anim Physiol Anim Nutr 2015;99:11422. https://doi.org/10.1111/jpn.12189

30.Janssen PH. Influence of hydrogen on rumen methane formation and fermentation balances through microbial growth kinetics and fermentation thermodynamics. Anim Feed Sci Technol 2010;160:1-22. https://doi.org/10.1016/j. anifeedsci.2010.07.002

31.Pengpeng $\mathrm{W}$, Tan Z. Ammonia assimilation in rumen bacteria: a review. Anim Biotechnol 2013;24:107-28. https://doi.org/ 


\subsection{0/10495398.2012.756402}

32. Buckel W. Usual enzymes involved in five pathways of glutamate fermentation. Appl Microbiol Biotechnol 2001;57: 263-73. https://doi.org/10.1007/s002530100773

33. Paster BJ, Russell JB, Yang CMJ, Chow JM, Woese CR, Tanner R. Phylogeny of the ammonia-producing ruminal bacteria Peptostreptococcus anaerobius, Clostridium sticklandii, and Clostridium aminophilum sp. nov. Int J Syst Bacteriol 1993;43:107-10. https://doi.org/10.1099/00207713-43-1-107

34. Newbold CJ, Lassalas B, Jouany JP. The importance of methanogens associated with ciliate protozoa in ruminal methane production in vitro. Lett Appl Microbiol 1995;21:230-4. https://doi.org/10.1111/j.1472-765x.1995.tb01048.x

35. Kingston-Smith AH, Davies TE, Edwards J, Gay A, Mur LAJ. Evidence of a role for foliar salicylic acid in regulating the rate of post-ingestive protein breakdown in ruminants and contributing to landscape pollution. J Exp Bot 2012;63: 3243-55. https://doi.org/10.1093/jxb/ers048

36. Russell JB, Mantovani HC. The bacteriocins of ruminal bacteria and their potential as an alternative to antibiotics. J Mol Microbiol Biotechnol 2002;4:347-55.

37. Megías MD, Hernández F, Madrid J, Martínez-Teruel A. Feeding value, in vitro digestibility and in vitro gas production of different by-products for ruminant nutrition. J Sci Food Agric 2002;82:567-72. https://doi.org/10.1002/jsfa.1081
38. Raab L, Cafantaris B, Jilg T, Menke K. Rumen protein degradation and biosynthesis: 1 . A new method for determination of protein degradation in rumen fluid in vitro. Br J Nutr 1983; 50:569-82. https://doi.org/10.1079/bjn19830128

39. Stiles DA, Bartley EE, Meyer RM, Deyoe CW, Pfost HB. Effect of expansion-processed mixture of grain and urea (Starea) on rumen metabolism in cattle and on urea toxicity. J Dairy Sci 1970;53:1436-47. https://doi.org/10.3168/jds.S0022-0302 (70)86412-8

40.Zain M, Sutardi T, Suryahadi, Ramli N. Effect of defaunation and supplementation methionine hydroxy analogue and branched chain amino acid in growing sheep diet based on palm press fiber ammoniated. Pak J Nutr 2008;7:813-6. https:// doi.org/10.3923/pjn.2008.813.816

41.Suryapratama W. Suhartati FM. Effect of supplementation of branched chain fatty acid on colony of ruminal bacteria and cell of protozoa. Anim Prod 2005;11:129-34.

42. Yang CMJ. Response of forage fiber degradation by ruminal microorganisms to branched-chain volatile fatty acids, amino acids, and dipeptides. J Dairy Sci 2002;85:1183-90. https:// doi.org/10.3168/jds.S0022-0302(02)74181-7

43. Chen G, Sniffen CJ, Russell JB. Fermentation of peptides and amino acids by monensin sensitive ruminal Peptostreptococcus. Appl Environ Microbiol 1988;54:2742-9. https:/doi.org/10. 1128/aem.54.11.2742-2749.1988 